\title{
Preliminary Study of the Targeted Cleaning of an Artificial Gypsum Layer on White Marble
}

\author{
Yan Liu ${ }^{1,2}$, Taoling Dong ${ }^{1,2}$, Kun Zhang ${ }^{1,2}$, Fuwei Yang ${ }^{1,2, *}$ and Liqin Wang ${ }^{1,2}$ \\ 1 Department of Preservation Technology for Cultural Heritage, Northwest University, Xi'an 710069, China; \\ liuyan197710@126.com (Y.L.); d1027454645@163.com (T.D.); zhangkun-1990@hotmail.com (K.Z.); \\ wangliqin@nwu.edu.cn (L.W.) \\ 2 Key Laboratory for the Preservation and Conservation of Cultural Heritage of Education Ministry, \\ Northwest University, Xi' an 710069, China \\ * Correspondence: yangfuwei@nwu.edu.cn
}

check for updates

Citation: Liu, Y.; Dong, T.; Zhang, K.; Yang, F.; Wang, L. Preliminary Study of the Targeted Cleaning of an Artificial Gypsum Layer on White Marble. Coatings 2021, 11, 37. https: //doi.org/10.3390/coatings11010037

Received: 28 November 2020 Accepted: 29 December 2020 Published: 1 January 2021

Publisher's Note: MDPI stays neutral with regard to jurisdictional clai$\mathrm{ms}$ in published maps and institutional affiliations.

Copyright: () 2021 by the authors. Licensee MDPI, Basel, Switzerland. This article is an open access article distributed under the terms and conditions of the Creative Commons Attribution (CC BY) license (https:// creativecommons.org/licenses/by/ $4.0 /)$.

\begin{abstract}
Targeting cleaning of the artificial gypsum layer on white marble was studied. It was conducted by means of the specific depletion of the calcium and sulfate ions by the barium carbonate scavenger, which led to the continuous dissolution and clearance of gypsum layer. The cleaning effect was evaluated by scanning electron microscopy with energy dispersive X-ray spectroscopy (SEM/EDX), X-ray diffraction (XRD), capillary suction, and color difference measurement. By this method, only the gypsum layer was cleared away and the carbonate substrate of marble was left intact at the same time. This method will be highly useful for the conservation of marble relics from surface weathering.
\end{abstract}

Keywords: gypsum layer; targeting cleaning; conservation; marble

\section{Introduction}

Gypsum is common on the surface of the calcareous stone relics [1]. It is mainly a weathering product of carbonate minerals under the attack of sulfur oxide pollutants [2]. The formation of a gypsum crust is often accompanied with the appearance alteration [3], surface dissolution [4], and structure disruption [5] of stone relics. The removal of this kind of harmful gypsum crust is thus believed to be necessary [6,7].

In the past, chemical, laser, and microblasting methods were developed successively for the removal of the gypsum crust on stone artifacts. Traditionally, basic carbonate, sodium citrate and exchange resin were common scavengers in chemical cleaning [8]. They can act as solvents, chelating agents, and ion exchangers during the cleaning process, respectively. Chemical cleaning can eliminate almost all of the gypsum crust efficiently. However, a large part of the chemical agents, such as ammonium carbonate, EDTA, surfactant, etc. [9], will be entrapped in the porous stone substrate during the cleaning process and cannot be easily removed, which may cause possible damages such as discoloration and even the acceleration of degradation. In addition, barium hydroxide was even proposed for the treatment of gypsum weathering crusts on stone artifacts. Theoretically, the slightly soluble gypsum can be converted into insoluble and protective barium sulfate layer in situ. However, this barium sulfate layer was found to be flaky in application, and the barium hydroxide method was believed to be risky [10]. Laser and microblasting have also been studied as physical cleaning tools. Under the irradiation of a high energy laser, the gypsum crust and other stains on stone artworks can be removed through gasification. Due to the good controllability, high accuracy and little impact on the environment, laser cleaning was once believed to be promising [11]. However, laser cleaning is too costly and beyond the reach of the conservation practice of most stone artifacts. Moreover, the ablation effect of lasers often leads to alterations in the composition and appearance [12] of the artifacts. Microblasting has also been considered in the cleaning of historic stones [13]. 
In this cleaning technique, abrasives with energy are used to break the bonding between the gypsum crust and the stone substrate. It is effective in the removal of the surface deposits for building stones [14]. However, as a mechanical method, the over-cleaning of blasting is normally noticeable. The gypsum crust and the stone substrate underneath are removed indiscriminately during the cleaning process. Therefore, microblasting should be cautiously selected for the cleaning of stone artifacts [15]. To sum up, these existing cleaning methods are not safe enough, and stone artifacts can be damaged during the removal process of the gypsum crust. In fact, sulfate attack is also widespread for concrete constructions in saline soil areas [16]. In this case, barium carbonate has been proven to be an effective inhibitor, which can remove soluble sulfates in the form of highly insoluble barium sulfate [17]. With this revelation, the removal of the harmful gypsum crust on stone relics can be performed when barium carbonate is adopted as a processing agent. However, to avoid the precipitation of barium sulfate on the surface of stones, the processing agent of barium carbonate cannot directly touch the gypsum weathering product in the treatment process.

In this paper, a novel method for the targeted removal of the gypsum weathering layer on white marble was developed. By this method, the gypsum layer was dissolved and swept away with the aid of the scavenger, barium carbonate, which was embedded in an absorbent cotton coating full of water before application on the surface of the gypsum layer. The carbonate substrate of the white marble, however, could not be affected, and remained intact. The cleaning effect was evaluated by scanning electron microscopy with energy dispersive X-ray spectroscopy (SEM/EDX), X-ray diffraction (XRD), capillary suction and color difference measurement.

\section{Experimental}

\subsection{Sample Preparation}

Analytical reagents were used throughout the experiment. Absorbent cotton, barium carbonate and sulfur dioxide were purchased from Sinopharm Group Co., Ltd. Local marble with the trade name of "Guangxi White" was used (Stonecube Stone Industry, Hezhou, China). The marble stone was mainly composed of calcite ( $\geq 98.0 \%)$. The marble specimens $(4.0 \mathrm{~cm} \times 4.0 \mathrm{~cm} \times 2.0 \mathrm{~cm})$ with gypsum layers were prepared by a sulphation method in a homemade climatic chamber. The concentration of sulfur dioxide, air flow and relative humidity in the chamber was set as $60 \mu \mathrm{g} / \mathrm{L}, 0.1 \mathrm{~L} / \mathrm{s}$ and $80 \%$, respectively [4]. After 60 days of sulphation, the specimens were taken out, rinsed with water, and dried naturally. The prepared gypsum layer was about $50 \mu \mathrm{m}$ in thickness.

The removal of the gypsum layer on the marble specimens was carried out according to the procedures in Figure 1. Firstly, the powder of barium carbonate was imbedded in the absorbent cotton to make a coating with a sandwich structure. The flexibility of absorbent cotton guaranteed the close fit of the cleaning pad with the surface of the stone samples. Then, enough water was introduced into the cotton coating by soaking. Finally, the marble specimens with gypsum layers were coated with the water-saturated cotton coating. After 1-3 days, the marble specimens were taken out, washed by purified water, and dried naturally before further investigations.

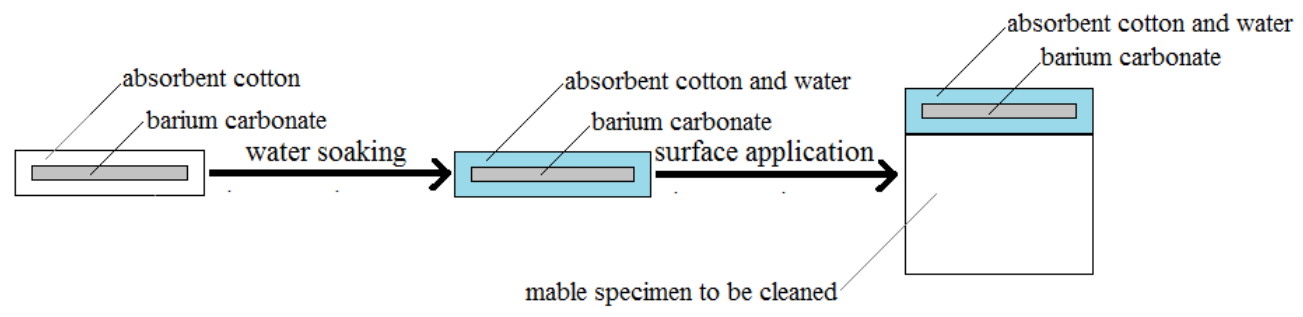

Figure 1. Strategy scheme of the removal procedures of the surface layer of gypsum on a marble specimen. 


\subsection{Characterization}

The microstructures of the samples were observed by scanning electron microscopy (SEM, FEI SIRION-100, $5.0 \mathrm{kV}$ of accelerating voltage and $8.0 \mathrm{~mm}$ working distance, Hillsboro, OR, USA). The thickness of the gypsum layer was measured according to the SEM image of the cross section of the sample.

EDX (Hitachi, Tokyo, Japan) analysis was carried out to detect the elemental composition of the samples. From every sample, five different points across the test surface were taken, and five sets of results were acquired.

The phase constituent of the samples was detected by X-ray diffraction (XRD, AXS D8 ADVANCE, scan range $2 \theta=10^{\circ}-80^{\circ}$, Tokyo, Japan). The marble specimens were analyzed directly, and no grinding/powdering was performed, which preserved the original features of the gypsum layer and the marble substrate. Grinding was carried out for barium carbonate samples to obtain uniform test samples. Before analyzing, the powdery samples were further paved and compacted in a sample cell. To monitor the composition change of the marble samples during the cleaning process, the XRD measurements were conducted after 24,36 and $72 \mathrm{~h}$.

The color difference of samples was determined by a chromatic meter (WSC-S, D65 illuminant, $8^{\circ} / \mathrm{d}$ optical geometry and CIE standard [18]).

The capillary suction values of the samples were tested according to the China national standard of natural stones [19].

\section{Results and Discussion}

The sample microstructures were investigated by SEM. The fresh marble was flat and compact in morphology (Figure 2a). After sulphation treatment, the surface of the sample became coarse and porous (Figure 2b), which was similar to the natural gypsum weathering layer [20]. The surface composition of the sample was also converted from calcium carbonate (calcite, $\mathrm{d}=3.86,2.29$ and $2.09 \AA$ ) to calcium sulfate dihydrate (gypsum, $\mathrm{d}=7.70,4.31,3.08,2.88$ and $2.69 \AA$ ) (Figure 3a). This means that a gypsum layer was formed during the sulphation process. In the field, this kind of gypsum layer is from the weathering of calcareous stone such as marble and limestone in air containing sulfur oxide pollutants [21].

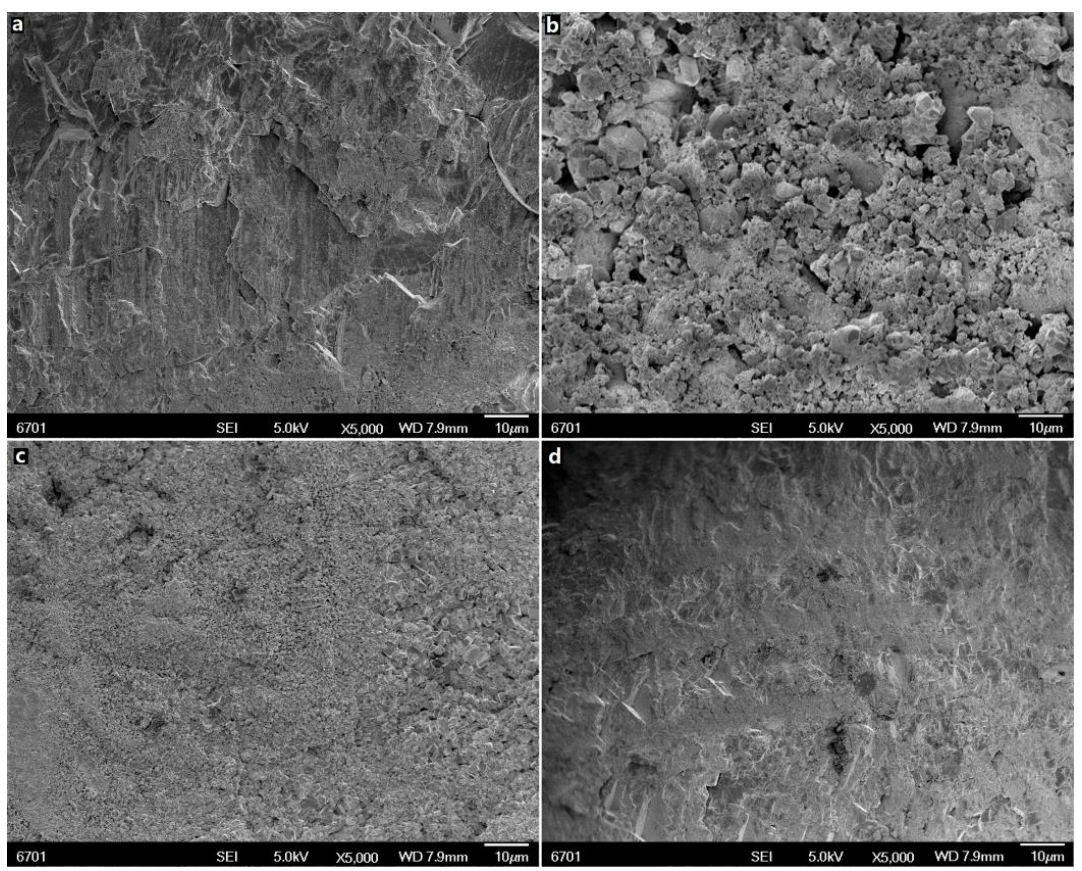

Figure 2. Micromorphology of samples: (a) marble; (b) gypsum layer; (c) partially cleaned gypsum layer $(24 \mathrm{~h}) ;(\mathrm{d})$ totally cleaned gypsum layer $(72 \mathrm{~h})$. 


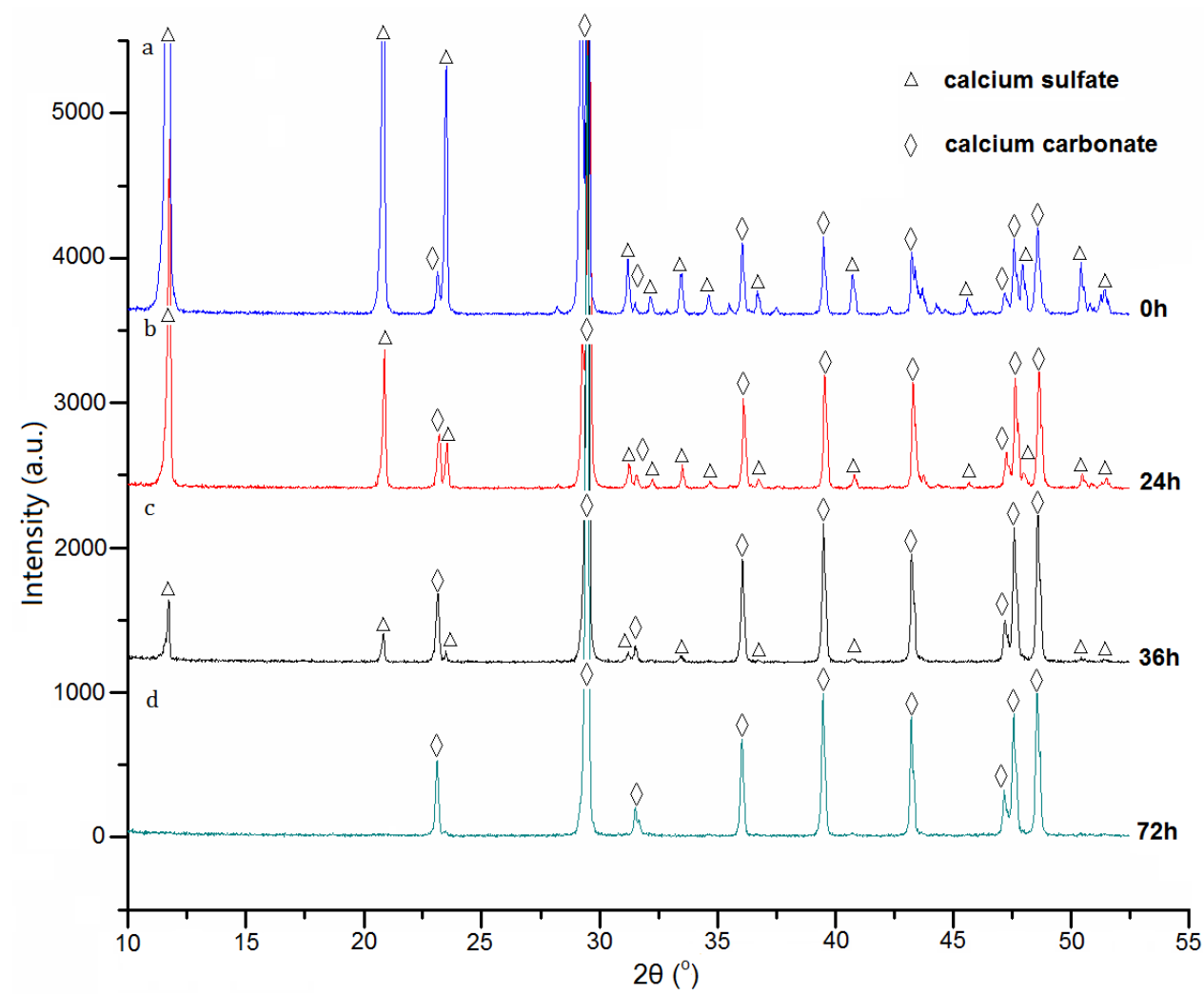

Figure 3. XRD results of surface sulphation marble samples after different treat time. (a) $0 \mathrm{~h}$, (b) $24 \mathrm{~h}$, (c) $36 \mathrm{~h},(\mathbf{d}) 72 \mathrm{~h}$.

The removal effects of the proposed method in Figure 1 were investigated by SEM, XRD and EDX characterization. From the SEM images, it was observed that the surface morphology of the samples changed significantly with the treating time. After treatment for $24 \mathrm{~h}$, the coarse and porous structures of the gypsum layer (Figure 2b) disappeared, and the surface of the sample became flat and compact (Figure 2c). After treatment for $72 \mathrm{~h}$, the surface morphology (Figure $2 \mathrm{~d}$ ) of the sample resembled that of fresh marble (Figure 2a). The results of XRD are highly consistent with the ones of SEM. As the cleaning treatment progressed $(0-36 \mathrm{~h})$, the diffraction peaks of calcite became stronger and the peaks of calcium sulfate became weaker (Figure $3 a-c)$. The calcite is from the marble substrate. Calcium sulfate, however, is from the gypsum layer. These results indicate that the gypsum layer was removed gradually. EDX results in Figure 4 can provide further evidence. With the progression of the cleaning treatment $(0-36 \mathrm{~h})$, the strength of the sulfur peaks reduced and the strength of the carbon peaks enhanced increasingly (Figure $4 a-c)$. After cleaning treatment for $72 \mathrm{~h}$, the diffraction peaks of calcium sulfate in Figure $3 \mathrm{~d}$ and the dispersive peak of sulfur in Figure $4 \mathrm{~d}$ are all absent, suggesting the total removal of the gypsum layer.

The composition change of the barium carbonate scavenger was also investigated. In the XRD results of Figure 5, the diffraction peaks of barium carbonate become weaker, while the ones of calcium carbonate and barium sulfate become gradually stronger during the treatment process. This is a result of the reaction between calcium sulfate and barium carbonate. The solubility of calcium sulfate is about 42 times larger than that of barium carbonate. This means that barium carbonate is closely encircled by the calcium cations and sulfate anions from the calcium sulfate layer [22] during the treatment process. As a result, the reaction between them [23] mainly happens in barium carbonate, and the insoluble reaction product of barium sulfate occurs within barium carbonate as well. The solubility of calcium sulfate, however, is about 40 times less than that of barium hydroxide. For the 
same reason, when barium hydroxide is used as a treating agent of a gypsum weathering layer, the barium sulfate product is on the stone surface [10].
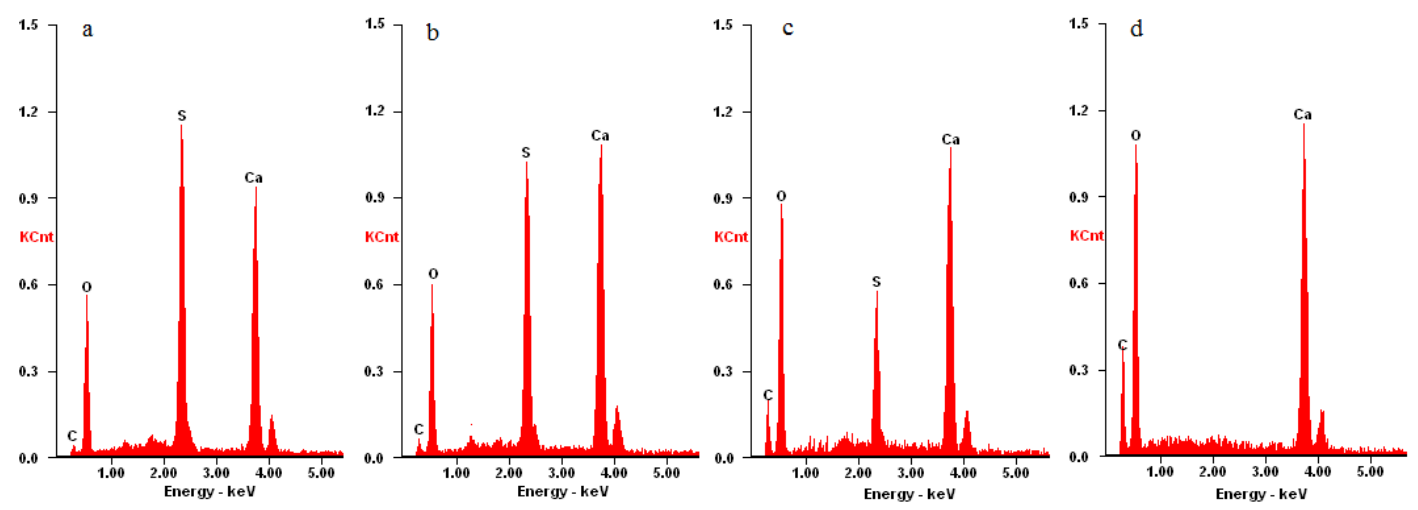

Figure 4. EDX results of the elemental composition change of the surface sulfation marble specimen after different treat times: (a) $0 \mathrm{~h}$; (b) $24 \mathrm{~h}$; (c) $36 \mathrm{~h}$; (d) $72 \mathrm{~h}$.

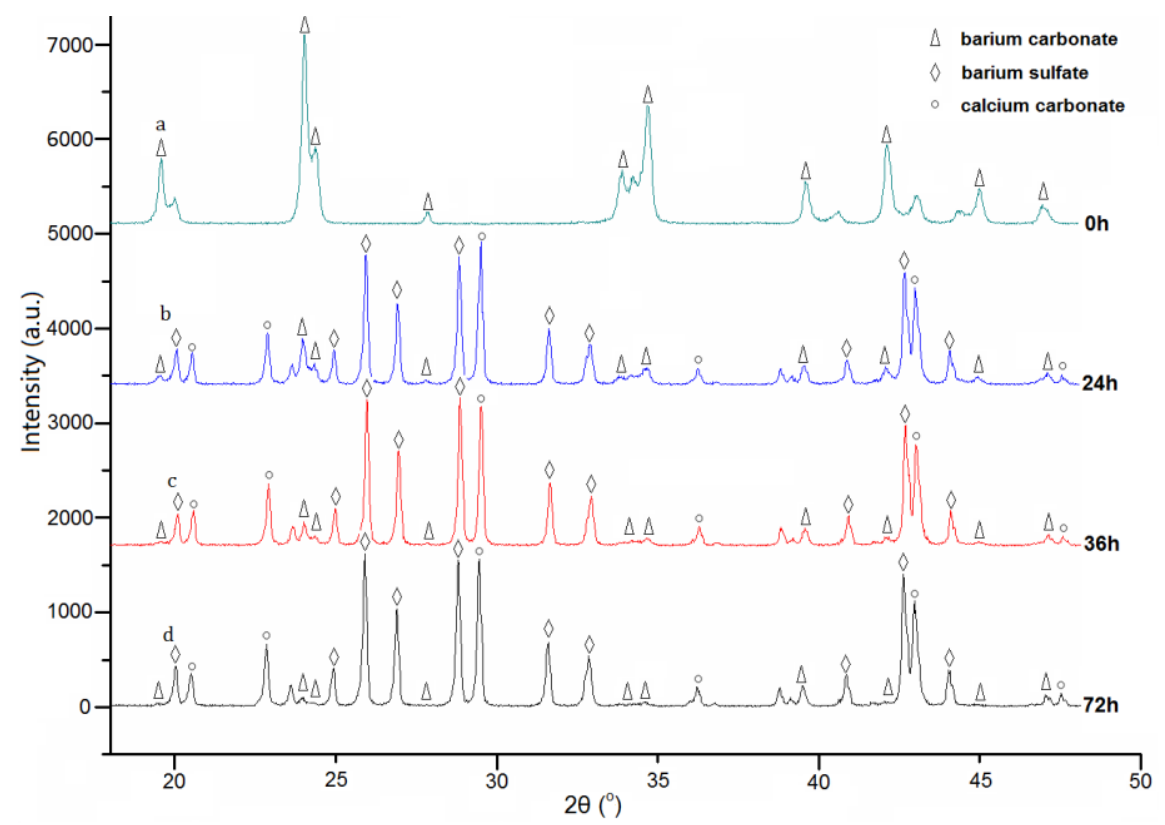

Figure 5. The phase transformation of the barium carbonate scavenger during the removal process: (a) $0 \mathrm{~h}$; (b) $24 \mathrm{~h} ;$ (c) $36 \mathrm{~h}$; (d) $72 \mathrm{~h}$.

This reaction between calcium sulfate and barium carbonate has an equilibrium constant of about $10^{5}$ [24] and can be carried out completely at room temperature. Due to the continuous depletion of the calcium and sulfate ions, the dissolution of the gypsum layer will continue until it is cleared completely. According to the above principle, this removal method is selective and safe. The mineral composition of marble is insoluble carbonate, and it cannot react with the barium carbonate scavenger. That means that only the gypsum layer is removed, and the carbonate substrate of the marble remains intact. Moreover, this removal method also has few residuals. The barium carbonate scavenger, and its products calcium carbonate and barium sulfate, are all insoluble substances. According to the solubility products, their residues in water can be as low as about $10^{-5} \mathrm{~mol} / \mathrm{L}$.

The removal effect can also be seen from both Figure 6 and Table 1 . The fresh marble is semitransparent, and the crystalline grains of calcite can be distinguished easily in Figure 6a. After sulphation treatment, a white and opaque calcium sulfate layer is produced. The crystalline grains of calcite under it are covered and become unrecognizable (Figure $6 \mathrm{~b}$ ). 
After cleaning treatment, the white calcium sulfate layer is eliminated completely, and the original appearance of marble is generally recovered (Figure 6c). As shown in Table 1, the color difference between the fresh marble and the marble with gypsum layer is 3.6, which is higher than the noticeable detection limit of the human eye of 3.0. This indicates that an appreciable appearance change has taken place after the surface weathering of marble. The color difference between the fresh marble and the marble after removal of gypsum layer, however, is just 0.8. This suggests that the gypsum layer on the marble has been completely removed, and the original appearance of the marble sample is restored.

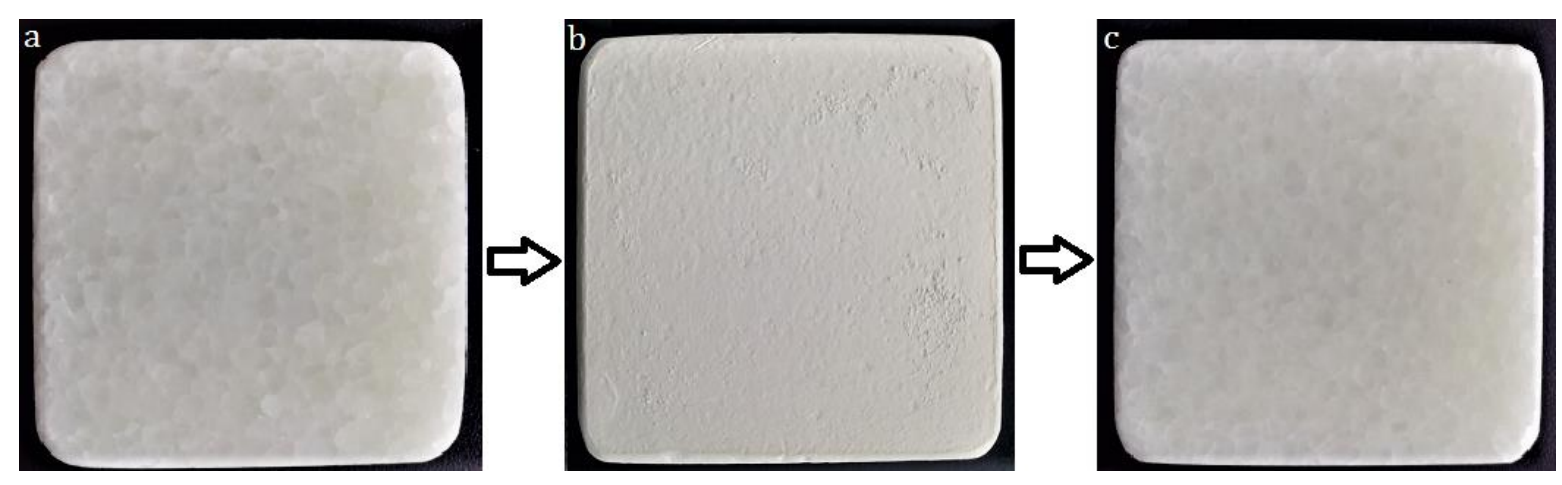

Figure 6. Photo pictures of the specimens: (a) marble; (b) marble with a gypsum layer; (c) marble after the cleaning of the gypsum layer.

Table 1. Properties of marble specimens before and after the gypsum layer removal treatment.

\begin{tabular}{cccc}
\hline Samples & Surface Composition & Color Difference $(\Delta \mathrm{E})$ & Capillary Suction (\%) \\
\hline Marble & Calcite & - & $0.08( \pm 0.03)$ \\
\hline Marble with gypsum layer & Calcium sulphate & $3.6( \pm 0.02)$ & $0.10( \pm 0.02)$ \\
\hline $\begin{array}{c}\text { Marble after removal of the } \\
\text { gypsum layer }\end{array}$ & Calcite & $0.8( \pm 0.03)$ & $0.09( \pm 0.02)$ \\
\hline
\end{tabular}

After sulphation treatment, the marble sample was covered by a gypsum layer and the capillary water adsorption increased from $0.08 \%$ to $0.10 \%$, which suggested a more loose and porous structure of the gypsum layer. However, the capillary water adsorption of the marble sample could only recover to $0.09 \%$ even after the total removal of the gypsum layer. This indicates that the marble became porous during the sulphation process. Therefore, the damage of surface weathering is irreversible to the stone structures.

Although most of the barium carbonate scavenger was converted into nontoxic barium sulfate, the residual barium carbonate is toxic, and innocent treatment is necessary. Before disposal, overnight soaking treatment of the absorbent cotton coating containing barium carbonate residual in a solution of sodium or potassium sulfate is recommended. By this method, the residual toxic barium carbonate can be completely converted into harmless barium sulfate.

\section{Conclusions}

A safe cleaning method was explored for the removal of the gypsum layer on white marble in this study. In this method, the gypsum layer is continuously dissolved and removed with the aid of the scavenger of barium carbonate, which was embedded in an absorbent cotton coating. The cleaning mechanism of this method lies on the specific reaction between calcium sulfate and the scavenger of barium carbonate in aqueous solution. That is, through the consumption of calcium and sulfate ions by barium carbonate, gypsum layer dissolves and disappears eventually. Due the high selectivity in sulfate removal, this study can preserve the carbonate stones from aggressive cleaning and is helpful for the conservation of the carbonate stone heritage suffering from sulfate attack. In addition, owe 
to the adoption of the absorbent cotton coating, the after treatment of this method is also convenient.

Author Contributions: Conceptualization, F.Y.; methodology, Y.L.; software, K.Z.; validation, T.D., F.Y. and Y.L.; formal analysis, Y.L.; investigation, Y.L.; resources, L.W.; data curation, Y.L.; writingoriginal draft preparation, Y.L.; writing - review and editing, F.Y. All authors have read and agreed to the published version of the manuscript.

Funding: This research was funded by Natural Science Foundation of China (B0501 21975202), Collaborative Innovation Team Foundation of University in Gansu Province, China (2017C-20), Key R \& D Program in Shaanxi Province, China (2019ZDLSF07-05, 2020SF-363).

Data Availability Statement: The research data in this study can be shared in the MDPI journal of Coatings.

Conflicts of Interest: We declare that there are no known conflicts of interest associated with this manuscript entitled "Selectional removal of the harmful gypsum layer on the calcareous historic stones" and there has been no significant financial support for this work that could have influenced its outcome.

\section{References}

1. Pozo-Antonio, J.S.; Ramil, A.; Rivas, T.; López, A.J.; Fiorucci, M.P. Effectiveness of chemical, mechanical and laser cleaning methods of sulphated black crusts developed on granite. Constr. Build. Mater. 2016, 112, 682-690. [CrossRef]

2. Suzuki, A.; Vettori, S.; Giorgi, S.; Carretti, E.; Di Benedetto, F.; Dei, L.; Benvenuti, M.; Moretti, S.; Pecchioni, E.; Costagliola, P. Laboratory study of the sulfation of carbonate stones through SWIR hyperspectral investigation. J. Cult. Herit. 2018, 32, 30-37. [CrossRef]

3. Ordóñez, S.; La Iglesia, Á.; Louis, M.; García-del-Cura, M.Á. Mineralogical evolution of salt over nine years, after removal of efflorescence and saline crusts from Elche's Old Bridge (Spain). Constr. Build. Mater. 2016, 112, 343-345. [CrossRef]

4. Liu, Y.; Yang, F.W.; Zuo, G.F.; Zhang, R.X.; Wei, G.F.; Ma, Q. Protection of the surface weathering stone artworks by a chemical conversion method. Constr. Build. Mater. 2018, 182, 210-214. [CrossRef]

5. Mooers, H.D.; Carlson, M.J.; Harrison, R.M.; Inkpen, R.J.; Loeffler, S. Correlation of gravestone decay and air quality 1960-2010. Atmos. Environ. 2017, 152, 156-171. [CrossRef]

6. Comite, V.; Álvarez de Buergo, M.; Barca, D.; Belfiore, C.M.; Bonazza, A.; La Russa, M.F.; Pezzino, A.; Randazzo, L.; Ruffolo, S.A. Damage monitoring on carbonate stones: Field exposure tests contributing to pollution impact evaluation in two Italian sites. Constr. Build. Mater. 2017, 152, 907-922. [CrossRef]

7. Iqbal, M. Perception of darkening of stone façades and the need for cleaning. Int. J. Sus. Built. Environ. 2013, 2, 65-72. [CrossRef]

8. Moropoulou, A.; Kefalonitou, S. Efficiency and countereffects of cleaning treatment on limestone surfaces-investigation on the Corfu Venetian Fortress. Build. Environ. 2002, 37, 1181-1191. [CrossRef]

9. Dei, L.; Baglioni, P.; Sarti, G.; Ferroni, E. Aging effects on ammonium carbonate/acetone solutions and cleaning of works of art. Stud. Conserv. 1996, 41, 9-18. [CrossRef]

10. van Hees, R.; Veiga, R.; Slížková, Z. Consolidation of renders and plasters. Mater. Struct. 2017, 50, 65. [CrossRef]

11. Senesi, G.S.; Allegretta, I.; Porfido, C.; De Pascale, O.; Terzano, R. Application of micro X-ray fluorescence and micro computed tomography to the study of laser cleaning efficiency on limestone monuments covered by black crusts. Talanta 2018, 178, 419-425. [CrossRef] [PubMed]

12. Grossi, C.M.; Benavente, D. Colour changes by laser irradiation of reddish building limestones. Appl. Surf. Sci. 2016, 384, 525-529. [CrossRef]

13. Godet, M.; Vergès-Belmin, V.; Gauquelin, N.; Saheb, M.; Monnier, J.; Leroy, E.; Bourgon, J.; Verbeeck, J.; Andraud, C. Nanoscale investigation by TEM and STEM-EELS of the laser induced yellowing. Micron 2018, 115, 25-31. [CrossRef] [PubMed]

14. Carvalhão, M.; Dionísio, A. Evaluation of mechanical soft-abrasive blasting and chemical cleaning methods on alkyd-paint graffiti made on calcareous stones. J. Cult. Herit. 2015, 16, 579-590. [CrossRef]

15. Iglesias-Campos, M.Á.; Prada Pérez, J.L.; García Fortes, S. Spot analysis to determine technical parameters of microblasting cleaning for building materials maintenance. Constr. Build. Mater. 2017, 132, 21-32. [CrossRef]

16. Yu, D.M.; Guan, B.W.; He, R.; Xiong, R.; Liu, Z.Z. Sulfate attack of Portland cement concrete under dynamic flexural loading: A coupling function. Constr. Build. Mater. 2016, 115, 478-485. [CrossRef]

17. Carmona-Quiroga, P.M.; Blanco-Varela, M.T. Use of barium carbonate to inhibit sulfate attack in cements. Cement Concrete Res. 2015, 69, 96-104. [CrossRef]

18. CIE Standard Illuminants for Colorimetry_Part 2: CIE Standard Illuminants; BS ISO 10526-2007; CIE Central Bureau: London, UK, 2007.

19. Test Methods for Natural Facing Stones_Part 3: Test Methods for Bulk Density, True Density, True Porosity and Water Absorption; GB/T 9966.3-2001; General Administration of Quality Supervision, Inspection and Quarantine of the People's Republic of China: Beijing, China, 2001. 
20. De Kock, T.; Van Stappen, J.; Fronteau, G.; Boone, M.; De Boever, W.; Dagrain, F.; Silversmit, G.; Vincze, L.; Cnudde, V. Laminar gypsum crust on lede stone: Microspatial characterization and laboratory acid weathering. Talanta 2017, 162, 193-202. [CrossRef]

21. Lamhasni, T.; El-Marjaoui, H.; El Bakkali, A.; Ait Lyazidi, S.; Haddad, M.; Ben-Ncer, A.; Benyaich, F.; Bonazza, A.; Tahri, M. Air pollution impact on architectural heritage of Morocco: Combination of synchronous fluorescence and ATR-FTIR spectroscopies for the analyses of black crusts deposits. Chemosphere 2019, 225, 517-523. [CrossRef]

22. Tang, J.H.; Bullard, J.W.; Perry, L.N.; Feng, P.; Liu, J.P. An empirical rate law for gypsum powder dissolution. Chem. Geol. 2018, 498, 96-105. [CrossRef]

23. Petrou, A.L.; Terzidaki, A. Calcium carbonate and gypsum precipitation, crystallization and dissolution: Evidence for the activated steps and the mechanisms from the enthalpy and entropy of activation values. Chem. Geo. 2014, 381, 144-153. [CrossRef]

24. Torres, E.; Lozano, A.; Macías, F.; Gomez-Arias, A.; Castillo, J.; Ayora, C. Passive elimination of sulfate and metals from acid mine drainage using combined limestone and barium carbonate systems. J. Clean Prod. 2018, 182, 114-123. [CrossRef] 